\title{
Cytochrome P450 2D6
}

National Cancer Institute

\section{Source}

National Cancer Institute. Cytochrome P450 2D6. NCI Thesaurus. Code C17287.

Cytochrome P450 2D6 (497 aa, 56 kDa) is encoded by the human CYP2D6 gene. This protein plays a role in flavoprotein metabolism. 